\title{
Activation of MAPK Is Required for ROS Generation and Exocytosis in HMC-1 Cells Induced by Trichomonas vaginalis-Derived Secretory Products
}

\author{
Giimaa Narantsogt ${ }^{1,2, \dagger}$, Arim Min ${ }^{1, \dagger}$, Young Hee Nam¹, Young Ah Lee1, Kyeong Ah Kim¹, Gurbadam Agvaandaram², \\ Temuulen Dorjsuren², Jamel El-Benna ${ }^{3}$, Myeong Heon Shin ${ }^{1, *}$ \\ ${ }^{1}$ Department of Environmental Medical Biology, Institute of Tropical Medicine, Yonsei University College of Medicine, Seoul 03722, Korea; \\ ${ }^{2}$ Department of Basic Science, School of Pharmacy and Biomedicine, Mongolian National University of Medical Sciences, Ulaanbaatar, Mongolia; \\ ${ }^{3}$ DR-CNRS Centre de Recherche Biomedical, INSERM U773, Universite Paris \& Denis Diderot, Paris, France
}

\begin{abstract}
Trichomonas vaginalis is a flagellated protozoan parasite that causes vaginitis and cervicitis in women and asymptomatic urethritis and prostatitis in men. Mast cells have been reported to be predominant in vaginal smears and vaginal walls of patients infected with T. vaginalis. Mitogen-activated protein kinase (MAPK), activated by various stimuli, have been shown to regulate the transcriptional activity of various cytokine genes in mast cells. In this study, we investigated whether MAPK is involved in ROS generation and exocytotic degranulation in HMC-1 cells induced by T. vaginalis-derived secretory products (TvSP). We found that TvSP induces the activation of MAPK and NADPH oxidase in HMC-1 cells. Stimulation with TvSP induced phosphorylation of MAPK and p47 phox in HMC-1 cells. Stimulation with TvSP also induced up-regulation of CD63, a marker for exocytosis, along the surfaces of human mast cells. Pretreatment with MAPK inhibitors strongly inhibited TVSP-induced ROS generation and exocytotic degranulation. Finally, our results suggest that TVSP induces intracellular ROS generation and exocytotic degranulation in HMC-1 via MAPK signaling.
\end{abstract}

Key words: Trichomonas vaginalis, secretory product, mast cell, MAPK, ROS generation, exocytotic degranulation

\section{INTRODUCTION}

Trichomonas vaginalis is a flagellated protozoan parasite that causes vaginitis and cervicitis in women and asymptomatic urethritis and prostatitis in men [1-4]. Trichomoniasis is the most common curable sexually-transmitted infection [5]. More than 180 million people around the world are annually infected by this parasite $[1,6]$. In pregnant women, trichomonads are implicated in the premature rupture of membranes, premature delivery, and the delivery of low-birth-weight infants $[7,8]$. The pathogenesis induced by T. vaginalis infection begins with the attachment of the parasite to epithelial cells and subsequent stimulation of host cells by T. vaginalis-derived secretory products (TvSP), which induce pathogenic changes in host tissues, eliciting cytotoxicity and immune responses $[9,10]$. The

- Received 31 May 2015, revised 5 August 2015, accepted 14 August 2015.

*Corresponding author (myeong@yuhs.ac)

${ }^{\dagger}$ Giimaa Narantsogt and Arim Min equally contributed to this work.

(c) 2015, Korean Society for Parasitology and Tropical Medicine

This is an Open Access article distributed under the terms of the Creative Commons Attribution Non-Commercial License (http://creativecommons.org/licenses/by-nc/3.0) which permits unrestricted non-commercial use, distribution, and reproduction in any medium, provided the original work is properly cited. trichomonad adhesion to vaginal epithelial cells and the release of proteolytic enzymes contained in TvSP are considered to be major factors responsible for disruption of vaginal epithelial layers [11,12].

Mast cells have been reported to be predominant in vaginal smears and vaginal walls of patients infected with T. vaginalis $[13,14]$. Mast cells can participate in direct killing of organisms by phagocytosis and reactive oxygen species (ROS) production [15]. ROS generation by membrane-localized NOX is a main cell signaling mechanism associated with tissue inflammation [16], and this may be dependent on the level of ROS production $[17,18]$. NOX2 is controlled by phosphorylation of cytosolic component $\mathrm{p} 47^{\text {phox }}[19]$. Degranulation of mast cells is essential for host defense against parasitic infections, where they play an important role in innate and adaptive immune responses [20]. CD63 is a component of granular membranes and is used as a marker for exocytosis [16]. Recent studies showed that CD63 is known to be expressed in intracellular membranes, such as secretory lysosomes, including serotonincontaining granules [21,22].

The mitogen-activated protein kinase (MAPK) cascade is an 
important signaling pathway in immune responses $[17,23,24]$. The activation of MAPK cascades involved various biological responses of proliferation [25], migration [26], apoptosis [27,28], cytokine expression [29], and degranulation [23] in various cells. In mammalian cells, MAPK signaling comprises 3 major subfamilies, such as extracellular signal-regulated kinase (ERK), p38 MAP kinase, and c-Jun N-terminal kinase (JNK) [29-31]. Although previous studies have demonstrated that MAPK pathways are involved in the up-regulation of IL-8 production in neutrophils activated by T. vaginalis [29] and phosphorylation of $\mathrm{p} 38$ MAPK and ERK in T. vaginalis-infected HeLa cells [25], none have reported on the relationships between MAPK and TvSP-induced human mast cell activation. Therefore, in this study, we aimed to investigate the role of MAPK signaling on TvSP-induced ROS generation and exocytotic degranulation in HMC-1 cells.

\section{MATERIALS AND METHODS}

\section{Reagents}

The following reagents were purchased from Calbiochem (Gibbstown, New Jersey, USA): Platelet-activating factor (PAF) was purchased from Biomol (Plymouth Meeting, Pennsylvania, USA). Antibodies (Ab) specific for phospho-ERK1/2, phospho-p38MAPK, phospho-JNK1/2, total-JNK1/2, totalERK1/2, total-p38 MAPK and $\beta$-actin were purchased from Cell Signaling Technology (Danvers, MA, USA). All other reagents were purchased from Sigma Chemical Company (St. Louis, Missouri, USA). Anti-p47 $7^{\text {phox }}$ antibody was purchased from BD Biosciences (San Jose, California, USA) and anti-phosphop4 $7^{\text {phox }}$ antibody was kindly donated by Dr. Jamel El-Benna. Phycoerythrin (PE)-conjugated anti-human CD63 monoclonal antibody (mAb) was purchased from Biolegend (San Diego, California, USA). All other reagents were purchased from Sigma Chemical Company unless otherwise stated.

\section{Cultivation of $T$. vaginalis trophozoites and preparation of secretory products (TVSP)}

T. vaginalis was axenically subcultivated at $37^{\circ} \mathrm{C}$ with Diamond's trypticase yeast extract-maltose (TYM) medium with $10 \%$ heat inactivated horse serum (Gibco/Invitrogen, Gaithersburg, Maryland, USA) and 0.5\% penicillin/streptomycin (Gibco/Invitrogen). T. vaginalis for the preparation of TvSP was obtained from logarithmically growing cells. To obtain various doses of TvSP for HMC-1 stimulation, trichomonads $\left(1 \times 10^{7}\right.$ or $2 \times 10^{5}$ ) were washed once with Hank's balanced salt solution (HBSS) (Gibco/Invitrogen), resuspended in $1 \mathrm{ml} \mathrm{HBSS,}$ and incubated for $1 \mathrm{hr}$ at $37^{\circ} \mathrm{C}$ in order to collect TvSP. After incubation, culture supernatants were centrifuged for $10 \mathrm{~min}$ at 14,000 rpm and filtered through filter with $0.22 \mu \mathrm{m}$ pores, yielding the TvSP used in this study. Protein concentrations were measured by the BCA protein assay using bovine serum albumin as a standard.

\section{Cultivation of the human mast cell line}

HMC-1 cells were used as a source of human mast cells. HMC-1 cells were axenically subcultivated at $37^{\circ} \mathrm{C}$ with IMDM (Iscove's medium) (Gibco/Invitrogen), containing 10\% heat inactivated fetal bovine serum (FBS) (Biomedia, Foster City, California, USA) and 1\% penicillin/streptomycin in a $5 \% \mathrm{CO}_{2}$ incubator.

\section{Stimulation of human mast cells and pretreatment with MAPK inhibitors}

HMC- 1 cells $\left(1 \times 10^{5}\right.$ or $5 \times 10^{5} /$ well $)$ seeded in 48 - or 96 well tissue culture plates were stimulated for different time points with or without TvSP or PAF. In addition, HMC-1 cells $\left(1 \times 10^{5} /\right.$ well $)$ were pretreated for $30 \mathrm{~min}$ with DMSO $(0.5 \%)$ at $37^{\circ} \mathrm{C}$ as a control. Cells were also pretreated with inhibitor of ERK1/2 (PD98059), p38MAPK (SB203580), and JNK (SP600125) at $50 \mu \mathrm{M}$, before stimulation with TvSP or PAF.

\section{Immunoblot analysis}

HMC- 1 cells $\left(5 \times 10^{5} /\right.$ well $)$ stimulated for different time points with or without TvSP or PAF in 24-well tissue culture plates in a $\mathrm{CO}_{2}$ incubator. After incubating for the indicated times, the reaction was stopped by brief centrifugation. The cells were lysed with lysis buffer $(20$ mM Tris-HCl, pH 7.5, 60 $\mathrm{mM} \beta$-glycerophosphate, $10 \mathrm{mM}$ EDTA, $10 \mathrm{mM} \mathrm{MgCl} 2,10 \mathrm{mM}$ $\mathrm{NaF}, 2 \mathrm{mM}$ DTT, $1 \mathrm{mM} \mathrm{Na} \mathrm{VO}_{4}, 1 \mathrm{mM}$ amidino-PMSF, 1\% Nonidet P-40, and $5 \mu \mathrm{g} / \mathrm{ml}$ leupeptin) on ice for $30 \mathrm{~min}$. After centrifuging at $12,000 \mathrm{~g}$ for $5 \mathrm{~min}$, the supernatants were diluted in SDS-PAGE loading buffer and heated at $100^{\circ} \mathrm{C}$ for $5 \mathrm{~min}$. The samples were stored at $-20^{\circ} \mathrm{C}$ until ready for use. Samples were subjected to 8 or $10 \%$ SDS-PAGE followed by electrotransfer onto Immobilon P polyvinylidene fluoride membranes (Millipore, Billerica, Massachusetts, USA). The membranes were blocked with 5\% nonfat dry milk in TBST at room temperature for $1 \mathrm{hr}$ and then incubated with primary antibodies against phospho-SAPK/JNK (Thr183/Tyr185) antibody, phos- 
pho-p38 MAPK (Thr180/Tyr182) antibody, phospho- ERK1/2 p44/42 (Thr202/Tyr204) antibody, phospho-p47 $7^{\text {phox }}$, SAPK/ JNK antibody, p38 MAPK antibody, ERK1/2 antibody, p47phox antibody or $\beta$-actin antibody at $4^{\circ} \mathrm{C}$ overnight. The membranes were subsequently soaked in HRP-conjugated anti-rabbit or goat IgG at room temperature for $1 \mathrm{hr}$. Immunoreactivity was detected using Lumi GLO (Cell Signaling).

\section{Measurement of intracellular ROS generation in HMC-1 cells}

Intracellular ROS accumulation in HMC-1 cells was measured using a green fluorescent probe, DCF-DA. HMC-1 cells $\left(1 \times 10^{5} /\right.$ well $)$ were pre-stained at $37^{\circ} \mathrm{C}$ for 10 min with $1 \mu \mathrm{M}$ of DCF-DA, which is rapidly oxidized to highly fluorescent DCF in the presence of intracellular $\mathrm{H}_{2} \mathrm{O}_{2}$. Cells were then incubated for up to 60 min with or without TvSP or PAF in 24well tissue culture plates in a $\mathrm{CO}_{2}$ incubator. Cells were washed twice with washing buffer, and DCF fluorescence was measured by flow cytometry using a FACS Calibur TM (BD Biosciences). At least 10,000 gated events were analyzed for

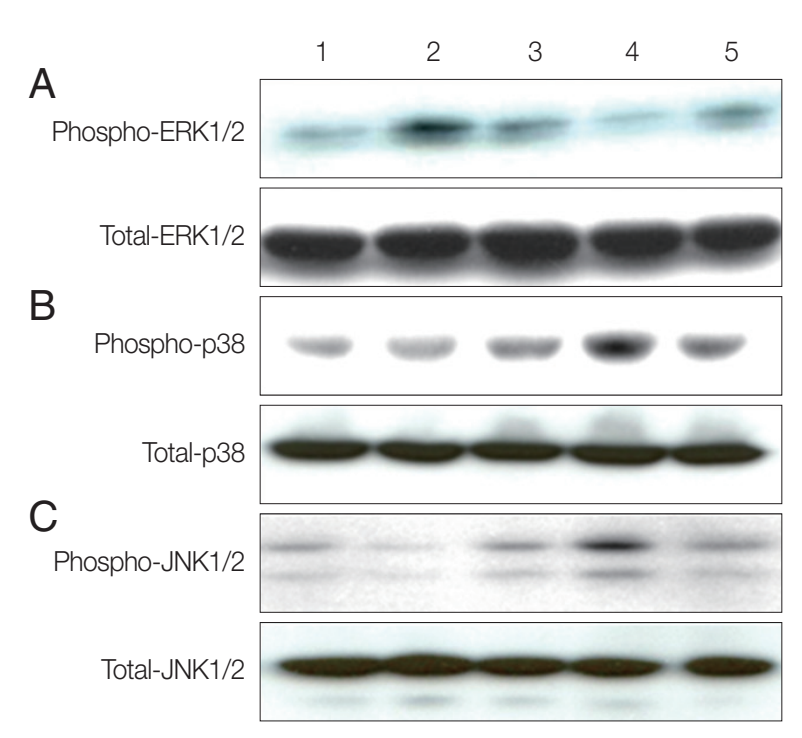

Fig. 1. TVSP induces activation of ERK1/2 (A), p38 (B), and JNK (C) in HMC-1 cells. Stimulation with TVSP induces phosphorylation of MAPK in HMC- 1 cells. HMC- 1 cells $\left(5 \times 10^{5} /\right.$ well) were incubated for 5,15 , and 30 min at $37^{\circ} \mathrm{C}$ with or without $T$. vaginalis $\left(2 \times 10^{5} /\right.$ well) in transwell system for western blotting, with antibodies against phospho-ERK1/2, total ERK1/2; phospho-p38, total p38; phospho-JNK1/2, total-JNK1/2; (10\% SDS-PAGE gel). Lane 1: HMC-1+medium, 30 min; Lane 2: HMC-1+TvSP, 5 min; Lane 3: HMC-1+TvSP, 15 min; Lane 4: HMC-1+TvSP, 30 min; Lane 5: HMC-1+PAF $1 \mu \mathrm{M}, 30 \mathrm{~min}$. PAF was treated as a positive control. each sample.

\section{Flow cytometric measurement of CD63 in HMC-1 cells}

Exocytotic degranulation induced by TvSP was measured as the mean fluorescent intensity of surface CD63 expression levels by staining HMC-1 cells with PE-conjugated anti-human CD63 mAb. To obtain surface CD63 expression levels, HMC-1 cells $\left(1 \times 10^{5}\right)$ were stimulated with or without TvSP and PAF for up to $60 \mathrm{~min}$. Cells were then incubated for $30 \mathrm{~min}$ at $4^{\circ} \mathrm{C}$ with PE-conjugated anti-CD63 mAb or isotype control $\mathrm{Ab}$, and washed 3 times with FACS buffer and then analyzed by flow cytometry. An appropriate irrelevant isotype control was used to measure nonspecific binding. The mean fluorescence intensity of CD63 expression for at least 10,000 cells from each sample was measured by flow cytometry.

\section{Statistical analysis}

The results are expressed as means \pm SD of 3 independent experiments. Student's $t$-test was used for all statistical analyses, and all $P$-values $<0.05$ were considered statistically significant.

\section{RESULTS}

\section{Effect of TvSP on MAPK activation in HMC-1}

To determine whether TvSP could induce activation of MAPK (ERK1/2, p38 MAPK, and JNK) in human mast cells. As shown Fig. 1A, HMC-1 cells were stimulated with TvSP for various times 5, 15, and 30 min caused transient ERK1/2 activation. The phosphorylation of ERK1/2 induced by TvSP showed a peak at $5 \mathrm{~min}$ and declined after $15 \mathrm{~min}$. As shown Fig. 1B, C, TvSP significantly increased the phosphorylation of p38 MAPK, and JNK in HMC-1 cells, compared to cells treated

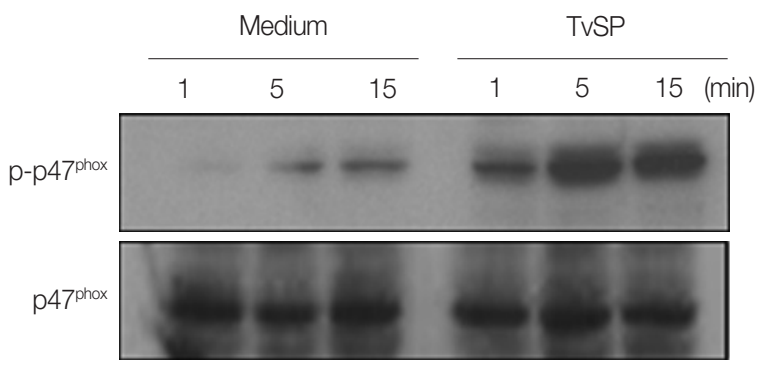

Fig. 2. TvSP induces phosphorylation of $\mathrm{p} 47^{\text {phox }}$ in HMC-1 cells. HMC-1 cells were stimulated for 1,5 , and 15 min with or without TVSP and then blotted with antibodies against phospho-p47 phox and total $\mathrm{p} 47^{\mathrm{phox}}$. The figure is representative of 3 experiments showing similar results. 

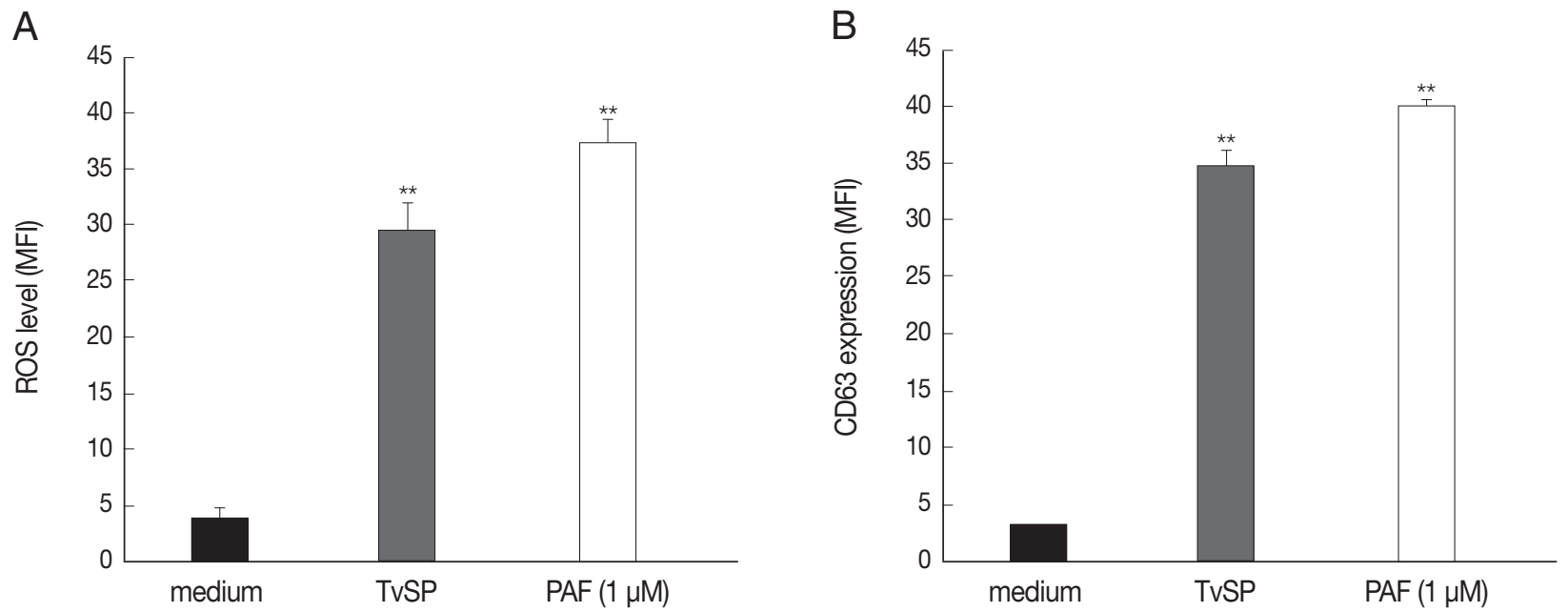

Fig. 3. TVSP induces ROS generation and exocytotic degranulation in $\mathrm{HMC}-1$ cells. $\mathrm{HMC}-1 \mathrm{cells}\left(1 \times 10^{5}\right)$ were stimulated for $1 \mathrm{hr}$ with or without TvSP or PAF $(1 \mu \mathrm{M})$. (A) Cells were stained with DCF-DA $(1 \mu \mathrm{M})$ for $10 \mathrm{~min}$. (B) CD63 expression. Data were analyzed by FACS and expressed the mean \pm SD from 3 independent experiments. ${ }^{* \star} P<0.01$ compared to control.
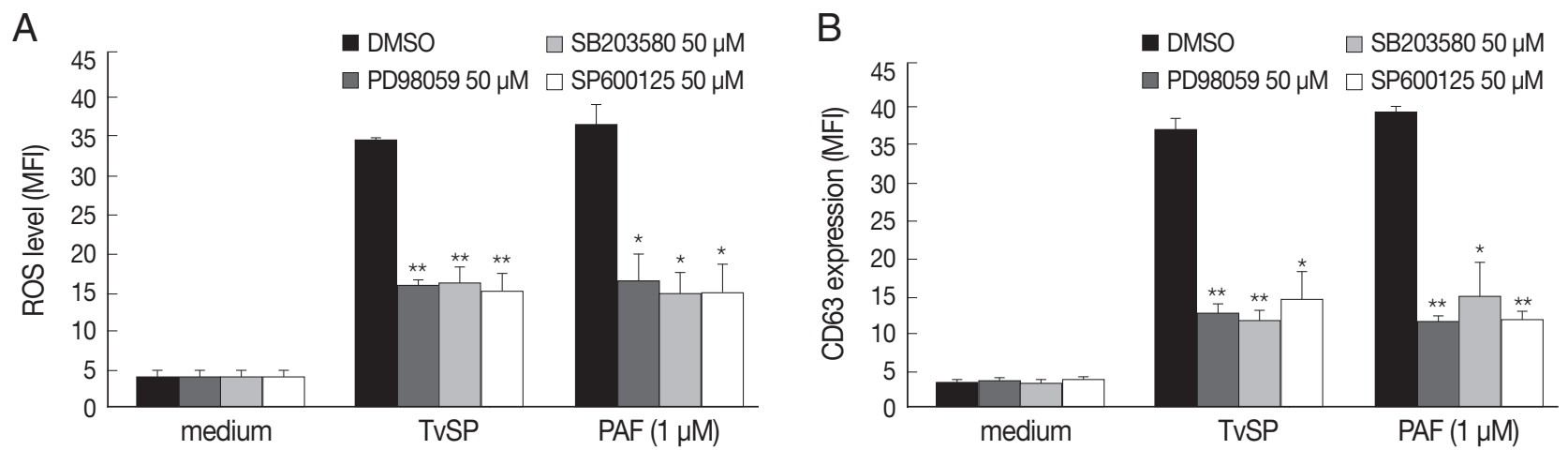

Fig. 4. TVSP induces ROS generation and exocytosis in HMC-1 cells via activation of MAPK. HMC-1 cells $\left(1 \times 10^{5}\right)$ were pretreated with inhibitors of ERK1/2, p38 MAPK, and JNK (50 MM) for 30 min before stimulation with TVSP. (A) Effect of inhibitors of MAPK on TvSP-induced intracellular ROS generation. (B) Effect of inhibitors of MAPK on TvSP-induced exocytotic degranulation in HMC-1 cells. Data were analyzed by FACS and expressed as the mean \pm SD from 3 independent experiments. Cytotoxicity of TVSP at the concentration used was observed. ${ }^{*} P<0.05,{ }^{*} P<0.01$ compared to the control.

with medium alone. TvSP induces activation of p38 MAPK, and JNK in HMC-1 in a time-dependent manner. Platelet activating factor (PAF), as a positive control, also induced phosphorylation of ERK1/2, p38 MAPK, and JNK in HMC-1 cells. We found that TvSP-induced phosphorylation of ERK1/2 is transient compared with phosphorylation of p38 MAPK and JNK.

\section{Effect of TvSP on NOX2 activation in HMC-1}

Next, we attempted to examine whether TvSP can induce phosphorylation of $\mathrm{p} 47^{\text {phox }}$ in HMC-1 cells. Phosphorylation of $\mathrm{p} 47^{\text {phox }}$ is and important step for NOX2 activation [19]. As shown in Fig.
2, stimulation with TvSP strongly induced phosphorylation of $\mathrm{p} 47^{\text {phox }}$ after 15 min of stimulation, compared with medium alone. TvSP induces NOX activation in a time-dependent manner.

\section{Effect of TVSP on the intracellular ROS generation and exocytotic degranulation in HMC-1}

We then performed flow cytometry analysis to assess whether TvSP induces intracellular ROS generation and exocytotic degranulation in HMC-1 cells. TvSP induced markedly up-regulation in intracellular ROS production (Fig. 3A) and exocytotic degranulation (Fig. 3B), compared with medium alone. 
Role of MAPK on intracellular ROS generation and exocytotic degranulation in TvSP-stimulated HMC-1 cells

To determine whether MAPK activation is involved in TvSPinduced intracellular ROS generation and exocytotic degranulation in HMC-1 cells, we examined the inhibitory effects of 3 MAPK inhibitors, ERK1/2 (PD98059), p38MAPK (SB203580), and JNK (SP600125), in human mast cells. Pretreatment with inhibitor of ERK1/2 (PD98059), p38MAPK (SB203580), and JNK (SP600125) markedly inhibited ROS generation and CD63 expression in HMC-1 cells induced by TvSP. TvSP induced ROS generation and surface upregulation of the exocytosis marker protein CD63 in HMC-1 cells via MAPK-dependent signaling (Fig. 4).

\section{DISCUSSION}

In this study, we demonstrated for the first time the role of MAPK signaling in TvSP-induced ROS generation and exocytotic degranulation in HMC-1 cells. MAPK signaling pathway is activated in response to various external stresses including parasite and bacterial infections, hyperosmolarity, and UV irradiation [32]. However, the role of MAPK on TvSP-induced human mast cell activation has not been reported.

Our results suggested that mast cells may play an important role in inflammatory reactions caused by T. vaginalis via MAPK signaling pathway. The amounts of phosphorylated p38 MAPK, and JNK increased at 5, 15, and $30 \mathrm{~min}$, respectively. In particular, TvSP-induced phosphorylation of ERK1/2 is transient compared with phosphorylation of p38 MAPK and JNK. Previous studies showed that persistent activation of ERK1/2 is associated with cell death $[23,28,31]$. In our study, TvSP-induced transient ERK1/2 phosphorylation seems to be associated with cell activation.

NADPH oxidase (also called NOX) has been established as a key enzyme for generating intracellular ROS [19]. Recent studies have shown that phosphorylation of cytosolic subunit p4 $7^{\text {phox }}$ plays an essential role in NOX2 activity, which is required for ROS generation [16,19]. Therefore, we examined whether TvSP could induce phosphorylation of the NOX2 cytosolic component $\mathrm{p} 47^{\text {phox }}$. Herein, phosphorylation of $\mathrm{p} 47^{\text {phox }}$ was increased by TvSP in a time dependent manner in HMC-1 cells, in accordance with a previous study which showed that NADPH oxidase activity and excessive ROS generation could be involved in inflammation and destruction, through increased p47 $7^{\text {phox }}$-Ser345 phosphorylation [26]. Additionally,
NADPH oxidase-derived intracellular ROS generation has been shown to mediate T. vaginalis-induced apoptosis of human neutrophils [31], migration of neutrophils [29] and monocytes [4], and activation of transcription factors in HMC1 cells [3], leading to an inflammatory response in the prostate epithelium [4].

Thus, we attempted to determine whether TvSP induces intracellular ROS production and exocytotic degranulation in HMC-1 cells by flow cytometry analysis. TvSP induced markedly increases in intracellular ROS production and exocytotic degranulation in HMC-1 cells, compared with medium alone. Previous studies evidenced that T. vaginalis can induce ROS generation in human neutrophils [31], migration of neutrophils [29], monocytes [4], and activation of transcription factors in HMC-1 cells [3], lead to an inflammatory response in prostate epithelium [4]. Taken together, our results suggest that TvSP-induced intracellular ROS generation and degranulation is associated with tissue inflammation.

Mast cells contain potent mediators, including histamine, serotonin, heparin, proteases, leukotrienes, and cytokines, and they are preformed and stored in granules from which they are released upon mast cell activation in a process called degranulation or regulated exocytosis $[15,21,33]$. Degranulation of mast cells has been reported in allergic inflammation and during infections with parasites. For example, the absence of CD63 results in a significant decrease in degranulation of mast cells [21], which translates into a reduction of acute allergic reactions in vivo, thus identifying CD63 as an important component of allergic inflammations [22]. A previous study also demonstrated that mast cells stimulated with TvSP release histamine and TNF- $\alpha$ [15]. In our study, we showed that mast cells play a role in the inflammation caused by T. vaginalis via exocytotic degranulation, as TvSP significantly increased exocytotic degranulation in HMC-1 cells. Nevertheless, we were unable to discern which signaling mechanism is involved in TvSP-induced human mast cell activation during inflammatory responses after acute T. vaginalis infection.

Previous studies have demonstrated that intracellular ROS generated from phorbol myristate acetate (PMA)-stimulated HMC-1 cell contribute to the production of inflammatory cytokines via p38 MAPK [30]. Additionally, phosphorylation of $\mathrm{p} 47^{\text {phox }}$ has been shown to play a key role in regulation of TNF- $\alpha$-induced ROS generation via MAPK signaling in endothelial cells [34]. MAPK is also known to mediate $47^{\text {phox }}$ phosphorylation on Ser345 in TNF-a-treated neutrophils [26]. 
Our study showed that MAPK activation plays a major role in ROS generation in HMC-1 cells induced by TvSP. In addition, we showed effects of 3 kinds of MAPK inhibitors such as PD98059, SB203580, and SP600125 on TvSP-induced exocytotic degranulation in HMC-1 cells. Pretreatment of HMC-1 cells with inhibitors of MAPK markedly suppressed CD63 expression in HMC-1 cells induced by TvSP. This result suggests that MAPK-dependent CD63 expression plays a key role in the exocytotic degranulation of HMC-1 cells induced by TvSP.

Previous studies have demonstrated that T. vaginalis-secreted lipid mediator $\mathrm{LTB}_{4}$ induces IL-8 production in mast cells via BLT-dependent activation of NF-kB and CREB [3]. Further, NOX2-derived ROS regulates surface trafficking of BLT1 during exocytotic degranulation in human eosinophils stimulated with $\mathrm{LTB}_{4}$ [16]. Accordingly, we plan to investigate whether lipid mediator $\mathrm{LTB}_{4}$, a component of TvSP, induces host BLTdependent activation of MAPK in human mast cells.

In conclusion, we showed that MAPK signaing is important for TvSP-induced ROS generation and exocytotic degranualtion in human mast cells. These results support our understanding of the pathogenesis and host-parasite relationships in T. vaginalis infections.

\section{ACKNOWLEDGMENTS}

This work was supported by Basic Science Research Program through the National Research Foundation of Korea (NRF) funded by the Ministry of Education, Science and Technology (2011-0021634).

\section{CONFLICT OF INTEREST}

We have no conflict of interest related to this work.

\section{REFERENCES}

1. World Health Organization. An overview of selected curable sexually transmitted diseases. Global Programme on AIDS Report. Geneva, Switzerland. World Health Organization. 1995.

2. Brill JR. Diagnosis and treatment of urethritis in men. Am Fam Physician 2010; 81: 873-878

3. Nam YH, Min D, Kim HP, Song KJ, Kim KA, Lee YA, Kim SH, Shin MH. Leukotriene B4 receptor BLT-mediated phosphorylation of NF- $\kappa B$ and CREB is involved in IL-8 production in human mast cells induced by Trichomonas vaginalis-derived secretory products. Microbes Infect 2011; 13: 1211-1220.
4. Seo MY, Im SJ, Gu NY, Kim JH, Chung YH, Ahn MH, Ryu JS. Inflammatory response of prostate epithelial cells to stimulation by Trichomonas vaginalis. Prostate 2014; 74: 441-449.

5. Johnston VJ, Mabey DC. Global epidemiology and control of Trichomonas vaginalis. Curr Opin Infect Dis 2008; 21: 56-64.

6. Kent HL. Epidemiology of vaginitis. Am J Obstet Gynecol 1991; 165: 1168-1176

7. Minkoff H, Grunebaum AN, Schwarz RH, Feldman J, Cummings $\mathrm{M}$, Crombleholme W, Clark L, Pringle G, McCormack WM. Risk factors for prematurity and premature rupture of membranes: a prospective study of the vaginal flora in pregnancy. Am J Obstet Gynecol 1984; 150: 965-972.

8. Soper DE, Bump RC, Hurt WG. Bacterial vaginosis and trichomonas vaginitis are risk factors for cuff cellulitis after abdominal hysterectomy. Am J Obstet Gynecol 1990; 163: 1016-1023.

9. Alderete JF, Lehker MW, Arroyo R. The mechanism and molecules involved in cytoadherence and pathogenesis of Trichomonas vaginalis. Parasitology 1995; 11:70-74.

10. Arroyo R, Gonzalez-Robles A, Martinez-Palomo A, Alderete JF. Signaling of Trichomonas vaginalis for amoeboid transformation and adhesin synthesis follows cytoadherence. Mol Microbiol 1993; 7: 299-309.

11. Gilbert RO, Elia G, Beach DH, Klaessig S, Singh BN. Cytopathogenic effect of Trichomonas vaginalis on human vaginal epithelial cells cultured in vitro. Infect Immun 2000; 68: 4200-4206.

12. Sommer U, Costello CE, Hayes GR, Beach DH, Gilbert RO, Lucas JJ, Singh BN. Identification of Trichomonas vaginalis cysteine proteases that induce apoptosis in human vaginal epithelial cells. J Biol Chem 2005; 280: 23853-23860.

13. Kobayashi TK, Fujimoto T, Okamoto H, Yuasa M, Sawaragi I. Association of mast cells with vaginal trichomoniasis in endocervical smears. Acta Cytol 1983; 27: 133-137.

14. Im SJ, Ahn MH, Han IH, Song HO, Kim YS, Kim HM, Ryu JS. Histamine and TNF- $\alpha$ release by rat peritoneal mast cells stimulated with Trichomonas vaginalis. Parasite 2011; 18: 49-55.

15. Urb M, Sheppard DC. The role of mast cells in the defence against pathogens. PLoS Pathog 2012; 8: 1-3.

16. Min A, Lee YA, Kim KA, El-Benna J, Shin MH. NOX2-derived ROS-mediated surface translocation of BLT1 is essential for exocytosis in human eosinophils induced by LTB4. Int Arch Allergy Immunol 2014; 165: 40-51.

17. Son Y, Cheong YK, Kim NH, Chung HT, Kang DG, Pae HO. Mitogen-activated protein kinases and reactive oxygen species: how can ROS activate MAPK pathways? J Sig Trans 2011; 1-6.

18. Dikalov S. Cross talk between mitochondria and NADPH oxidase. Free Radic Biol Med 2011; 51: 1289-1301.

19. Maalej KM, Chiandotto M, Nedelec MH, Bedouhene S, Gougerot-Pocidalo MA, Dang PM, El-Benna J. Zymosan induces NADPH oxidase activation in human neutrophils by inducing the phosporylation $47^{\text {phox }}$ and the activation of Rac2: involvement of protein tyrosine kinases, PKC, ERK1/2 and p38 MAPkinase. Biochem Pharmacol 2013; 85: 92-100.

20. Halova I, Draberova L, Draber P. Mast cell chemotaxis-chemoat- 
tractants and signaling pathways. Front Immunol 2012; 3: 1-19.

21. Kraft S, Jouvin MH, Kulkarni N, Kissing S, Morgan ES, Dvorak AM, Schoder B, Saftig P, Kinet JP. The tetraspanin CD63 is required for efficient IgE-mediated mast cell degranulation and Anaphylaxis. J Immunol 2013; 191: 2871-2878.

22. Valadi H, Ekstrom K, Bossios A, Sjostrand M, Lee JJ, Lotvall JO. Exosome mediated transfer of mRNAs and microRNAs is a novel mechanism of genetic exchange between cells. Cell Biol 2007; 9: 654-659.

23. Min YD, Choi CH, Bark H, Son HY, Park HH, Lee S, Park JW, Park EK, Shin HI, Kim SH. Quercetin inhibits expression of inflammatory cytokines through attenuation of NF-kB and p38 MAPK in HMC-1 human mast cell line. Inflamm Res 2007; 56: 210-215.

24. Lee JW, Kim JH. Activation of the leukotriene B4 receptor 2-reactive oxygen species (BLT2-ROS) cascade following detachment confers anoikis resistance in prostate cancer cells. J Biol Chem 2013; 288: 30054-30063.

25. Chang JH, Park JY, Kim SK. Dependence on p38 MAPK signaling in the up-regulation of TLR2, TLR4 and TLR9 gene expression in Trichomonas vaginalis-treated HeLa cells. Immunology 2006; 118: 164-170.

26. Dang PM, Stensballe A, Boussetta T, Raad H, Dewas C, Kroviarski Y, Hayem G, Jensen ON, Gougerot-Pocidalo MA, El-Benna J. A specific $\mathrm{p} 47^{\text {phox }}$-serine phosphorylated by convergent MAPKs mediates neutrophil NADPH oxidase priming at inflammatory sites. J Clin Invest 2006; 116: 2033-2043.

27. Ryang YS, Chang JH, Park JY. Involvement of MAP kinases in apoptosis of macrophage treated with Trichomonas vaginalis.
Yonsei Med J 2004; 45: 751-754.

28. Sim S, Yong TS, Park SJ, Im K, Kong Y, Ryu JS, Min DY, Shin MH. NADPH oxidase-derived reactive oxygen species-mediated activation ERK1/2 is required for apoptosis of human neutrophils induced by Entamoeba histolytica. J Immunol 2005; 174: 42794288.

29. Ryu JS, Kang JK, Jung SY, Shin MH, Kim JM, Park H, Min DY. Production of interleukin-8 by human neutrophils stimulated with T. vaginalis. Infect Immun 2007; 72: 1326-1332.

30. Kim JY, Ro JY. Signal pathway of cytokines produced by reactive oxygen species generated from phorbol myristate acetate- stimulated HMC-1 cells. Scand J Immunol 2005; 62: 25-35.

31. Song HO, Shin MH, Ahn MH, Min DY, Kim YS, Ryu JS. Trichomonas vaginalis: reactive oxygen species mediates caspase- 3 dependent apoptosis of human neutrophils. Exp Parasitol 2008; 118: 59-65.

32. Shin MH, Lee YA, Bae YS, Kita H, Kim Y, Ryu SH. The synthetic chemoattractant peptide WKYMVm induces superoxide production by human eosinophils via the phosphoinositide 3-kinase mediated activation of ERK1/2. Int Arch Allergy Immunol 2005; 137: 21-26.

33. Collington SJ, Williams TJ, Weller CL. Mechanisms underlying the localization of mast cells in tissues. Trend Immunol 2011; 32: 478-485.

34. Teng L, Fan LM, Meijles D, Li JM. Divergent effect of p47 $7^{\text {phox }}$ phosphorylation at S303-4 or S379 on tumor necrosis factor- $\alpha$ signaling via TRAF4 and MAPK in endothelial cells. Arterioscler Thromb Vasc Biol 2012; 32: 1488-1496. 
